\title{
Pengembangan Aplikasi Hebat Fluida Berbasis Android Untuk SMA Kelas XI Pada Materi Fluida Statis
}

\author{
Arum Wulandari*, Siti Idayatun, Christi Umita Meyputri \\ Universitas Negeri Jakarta, Indonesia
}

\begin{abstract}
The rapid development of technology and information has not been fully utilized in education system. There needs the development of Interactive learning media that can increase students' learning motivation. The aims of this study is to develop learning media for android-based Hebat Fluida applications for high school class XI on static fluid material. This study uses the Research and development (R\&D) method and the research model used is the DDD-E (Decide, Design, Develop, Evaluate) development model. This research was conducted with a feasibility test which has 3 aspects, the material aspect getting a percentage of $83,75 \%$, the media aspect getting a percentage of $90 \%$, and the language aspect getting a percentage of $85 \%$. It can be concluded that the average percentage of the feasibility test of the media is $86,25 \%$, which means it is very valid and suitable for use Hebat Fluida as a learning medium.
\end{abstract}

\begin{abstract}
ABSTRAK
Perkembangan teknologi dan informasi yang pesat belum dimanfaatkan secara maksimal dalam bidang Pendidikan. Perlu adanya media pembelajaran interaktif yang dapat meningkatkan motivasi belajar peserta didik. Penelitian ini bertujuan untuk mengembangankan media pembelajaran aplikasi hebat fluida berbasis android untuk SMA kelas XI pada materi fluida statis. Penelitian ini menggunakan metode Research and development (R\&D) dan model penelitian yang digunakan yaitu model pengembangan DDD-E (Decide, Design, Develop, Evaluate). Penelitian ini dilakukan dengan uji kelayakan yang memiliki 3 aspek yaitu aspek materi mendapatkan presentase $83.75 \%$, aspek media mendapatkan presentase $90 \%$, dan aspek Bahasa mendapatkan presentase $85 \%$. Dapat disimpulkan bahwa presentase rata-rata uji kelayakan media sebesar $86.25 \%$ yang artinya sangat valid dan layak digunakan sebagai media pembelajaran.
\end{abstract}

CONTACT

arumwulandari015@gmail.com

KEYWORDS

Aplikasi Android,

Pengembangan, Fluida Statis

Received: 26/01/2021

Revised: 30/02/2021

Accepted: 20/04/2021

Online: $25 / 04 / 2021$

Published: 30/04/2021

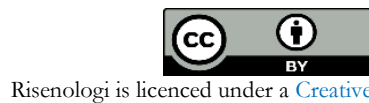

Commons Attribution 4.0 Internation Public Licence (CC-BY 4.0)

\section{INTRODUCTION}

Perkembangan teknologi, informasi dan komunikasi di Indonesia berkembang sangat cepat. Dilansir dari Prabowo (2020), jumlah pengguna internet di Indonesia mengalami peningkatan di mana pada tahun 2018 terdapat sebesar 171,2 juta jiwa pengguna dan pada kuartal II tahun 2020 mencapai 196,7 juta jiwa. Perkembangan teknologi turut mempengaruhi ilmu pengetahuan dalam dunia pendidikan. Pelaksanaan pembelajaran yang memanfaatkan teknologi dapat mempermudah dalam proses pembelajaran (e.g., Bakri et al., 2019a; Bakri \& Permana, 2021, Sumardani, 2020). Peserta didik saat ini juga dapat menerima proses pembelajaran dengan menggunakan teknologi baru dengan cepat dan mudah (Hubackova \& Semradova, 2016). Hal ini sejalan dengan pendapat Selwyn \& Neil (2011), yang menyatakan teknologi digital telah digunakan dalam lembaga pendidikan sebagai wadah untuk mendukung proses pembelajaran, sarana dalam mengakses informasi, atau sebagai alat pembelajaran yang menunjang kegiatan belajar. Contohnya penggunaan teknologi augmented reality (e.g., Bakri et al., 2019b; Bakri, 2019c; Bakri \& Wahyuni., 2021; Sumardani \& Wulandari, 2019; Sumardani, \& Saraswati, 2020; Sumardani \& Ramadhan, 2020) atau virtual reality (e.g., Sumardani \& Midaraeni, 2019; Sumardani \& Putri, 2020), e-learning (e.g., Sumardani \& Putri, 2020), dan mobile learning (e.g., Widyanirmala et al., 2014) dalam pembelajaran. Selain itu, dengan memanfaatkan teknologi informasi dan komunikasi sebagai media pembelajaran mendukung salah satu prinsip pembelajaran untuk meningkatkan hasil belajar yang efisien dan efektif (Kemdikbud, 2016).

Mobile learning dalah sebuah metode pembelajaran yang baru dalam memaksimalkan penggunaan tenologi mobile atau yang sering disebut smartphone. Smartphone memiliki kemampuan seperti halnya komputer yang memungkinkan pengguna melakukan komunikasi seperti menelpon dan mengirim pesan singkat. Smartphone dapat digunakan sebagai alternatif media pembelajaran yang dapat diimplementasikan menjadi multimedia interaktif dengan ditambahkan musik, gambar, game, dan lain sebagainya. Melalui pengembangan mobile learning peserta didik dapat lebih aktif mengikuti proses belajar sepanjang waktu (Kurniawan, 2017). Mobile learning punya potensi besar untuk menjelaskan konsep fisika secara lebih mudah (Bakri, 2021; Sumardani et al., 2019; Sumardani et al, 2020). 
Media interaktif adalah proses penyampaian pesan yang disajikan dalam bentuk vidio atau gambar yang ditujukan kepada penonton dengan pengendalian yang dilakukan oleh komputer. Media interaktif tidak hanya menonton tetapi juga terdapat audio yang dapat didengar dalam menarik respon pengguna agar aktif dalam penyajiannya (Azhar \& Arsyad, 2004). Menurut Purbasari (2013) dalam penelitiannya mengenai media pembelajaran berbasis android materi dimensi tiga, membuktikan $83,49 \%$ peserta didik menyatakan bahwa media pembelajaran berbasis android layak untuk menunjang proses pembelajaran di SMA. Pembelajaran menggunakan media berbasis android ini interaktif untuk dikembangkan pada berbagai materi pelajaran, salah satunya pada pelajaran fisika.

Fisika adalah salah satu cabang dari ilmu sains yang aplikasinya dapat meningkatkan kemampuan berpikir analitik peserta didik. Kemampuan berpikir analitik peserta didik dapat dikembangkan dengan memanfaatkan fenomena alam sebagai bentuk implementasi dari ilmu fisika. Fisika adalah pelajaran yang memberikan pengetahuan mengenai alam semesta untuk melatih kemampuan berpikir dan bernalar, melalui kemampuan tersebut peserta didik dapat berkembang dan bertambah daya pikir dan pengetahuannya (Supardi, 2012). Berdasarkan hasil ujian nasional tahun 2018 dilansir dari Kementrian Pendidikan dan Kebudayaan menghasilkan bahwa fisika merupakan pelajaran yang memiliki capaian nilai rata-rata terendah setelah matematika dengan rerata 46.47 dari 100 (Kemendikbud, 2018). Pada hasil ujian nasional tahun 2019, materi mekanika fluida menjadi salah satu indikator yang mendapat nilai rendah sebesar 31,23 dibawah rata-rata nilai daya serap nasional sebesar 55,00 (Puspendik, 2019). Sedangkan kata Hebat merujuk pada kamus besar bahasa Indonesia yang berarti amat sangat (seru dan bagus), yang disimpulkan dengan sesuatu yang dapat diharapkan mendapat hasil yang bagus dengan proses yang seru, terutama dalam proses belajar fisika dengan materi fluida.

Oleh karena itu perlu dikembangkan media pembelajaran yang dapat membantu peserta didik mengikuti proses belajar dengan interaktif dan menari. Selanjutnya peneliti melakukan penelitian mengenai pengembangan media pembelajaran aplikasi android untuk SMA kelas XI pada materi fluida statis.

\section{METHODS}

Tujuan dari penelitian ini yaitu mengembangkan media pembelajaran aplikasi hebat fluida berbasis android untuk SMA kelas XI pada materi fluida statis. Penelitian ini menggunakan metode penelitian dan pengembangan yang sering disebut Research and development (R\&D). Research and development (R\&D) merupakan metode penelitian dan pengembangan yang digunakan untuk menghasilkan produk tertentu, dan menguji keefektifan produk tersebut (Sugiyono, 2017). Sedangkan model penelitian yang digunakan yaitu model pengembangan DDDE (Decide, Design, Develop, Evaluate). Model pengembangan ini merupakan salah satu model pengembangan yang digunakan dalam mengembangkan multimedia pembelajaran. Langkah-langkah yang tercantum dalam pengembangan model DDD-E meliputi keseluruhan prosedur penelitian dan pengembangan yang harus dilakukan oleh peneliti secara umum (Tegeh, 2014). Pengembangan multimedia ini terdiri atas:

1. Decide (menetapkan tujuan dan materi program) adapun tujuan pembelajaran yang akan dicapai yaitu:

a) Mengidentifikasi penerapan fluida dalam kehidupan sehari-hari

b) Menyimpulkan konsep tekanan hidrostatis

c) Menyimpulkan konsep hukum pascal

d) Menyimpulkan konsep prinsip hukum Archimedes

e) Menganalisis tegangan permukaan

f) Menganalisis kapilaritas

g) Menganalisis viskositas

2. Design (membuat struktur program)

Tahap selanjutnya adalah design atau merancang produk pembelajaran sebagai langkah untuk menghasilkan media pembelajaran yang telah ditentukan pada tahap decide, yang memiliki 4 langkah yaitu:

a) Membuat outline konten

b) Membuat flowchart

c) Membuat tampilan

d) Membuat storyboard

3. Develop (mengembangkan)

4. Evaluate (mengevaluasi) 


\section{RESULTS AND DISCUSSIONS}

Agustina, (2017) dalam penelitiannya mengenai pengembangan media pembelajaran fisika mobile learning berbasis android dengan tujuannya mengembangkan dan menghasilkan aplikasi media pembelajaran yang valid. Persamaan penelitian ini dengan penelitian penulis adalah pengembangan media pembelajaran berbasis android dan menggunakan materi fluida statis, sedangkan perbedaan penelitian ini dengan penelitian penulis adalah penggunaan model ADDIE (Analysis, Design, Development, Implementation dan Evaluation) sedangkan penulis menggunakan model DDD-E (Decide, Design, Develop, Evaluate). Adapun perbedaan selanjutnya yaitu pada penelitian ini hanya menampilakan soal sedangkan penelitian penulis menampilkan soal dan pembahasannya. Ronauli, (2018) dalam penelitiannya mengenai pengembangan aplikasi android dalam mendukung pembelajaran yang meliputi aplikasi mobile dan aplikasi web server. Persamaan penelitian ini dengan penelitian penulis yaitu penggunaan model penelitian ADDIE (Analysis, Design, Development, Implementation dan Evaluation). Adapun perbedaan penelitian ini mengembangkan produk, uji kelayakan, dan uji coba ke peserta didik, sedangkan penelitian penulis hanya mengembangkan produk dan uji kelayakan.

produk berupa aplikasi media pembelajaran yang dapat diakses melalui android dengan nama Hebat Fluida. Aplikasi ini didesain dengan friendly dan mudah serta menarik saat digunakan oleh peserta didik untuk mendukung proses belajar. Aplikasi ini dilengkap dengan materi, evaluasi dan eksperimen online.

Penelitian ini menggunakan model pengembangan DDD-E yang memiliki 4 tahap yaitu Decide, Design, Develop, Evaluate. Elemen-elemen dalam media pembelajaran yang dikembangkan meliputi:

1. Start Page, merupakan pertama sebelum ke menu utama.

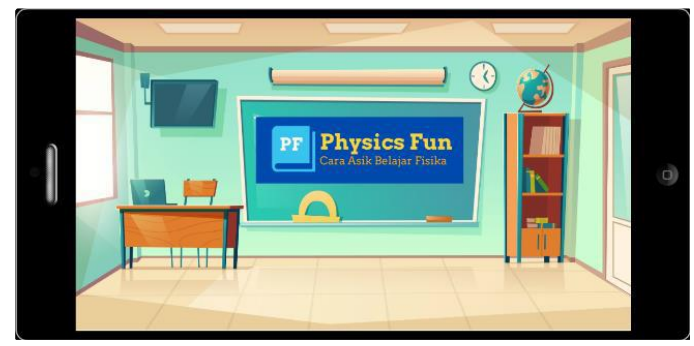

Gambar 1. Tampilan start page

2. Menu utama, terdapat beberapa menu yang meliputi menu KI-KD, menu peta konsep, menu materi, menu tokoh, menu evaluasi, menu eksperimen, menu penerapan, dan menu petunjuk.

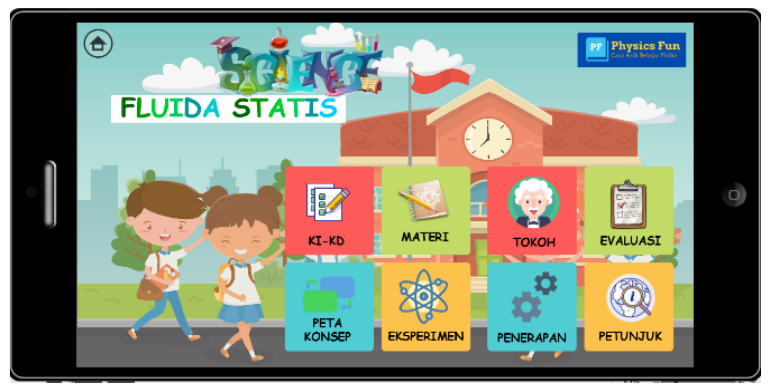

Gambar 2. Tampilan menu utama

3. Menu KI-KD, terdapat kompetensi inti, kompetensi dasar, dan tujuan pembelajaran sesuai dengan materi yang ditentukan yaitu fluida statis.

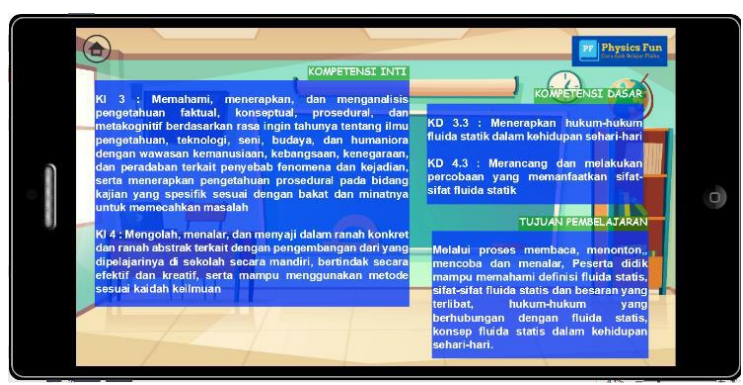


Gambar 3. Tampilan menu KI-KD

4. Menu peta konsep, suatu bagan sistematis untuk mewakili materi yang akan dijelaskan di dalam aplikasi tersebut.

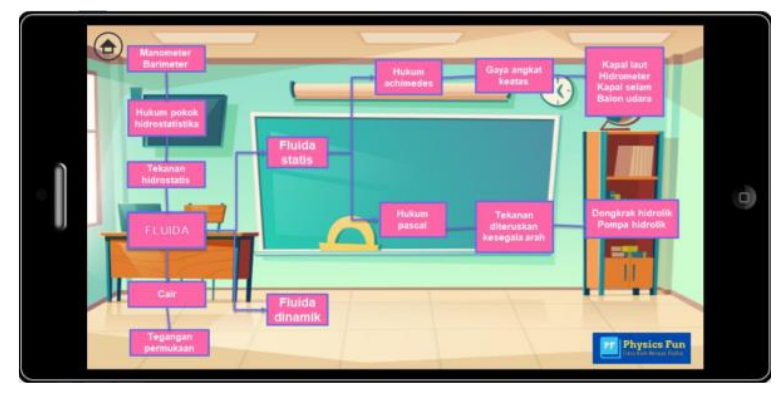

Gambar 4. Tampilan menu peta konsep

5. Menu materi, terdapat audio yang berisi penjelasan materi, terdapat info fisika yang berisi video mengenai fluida statis yang berhubungan dengan kehidupan sehari-hari.

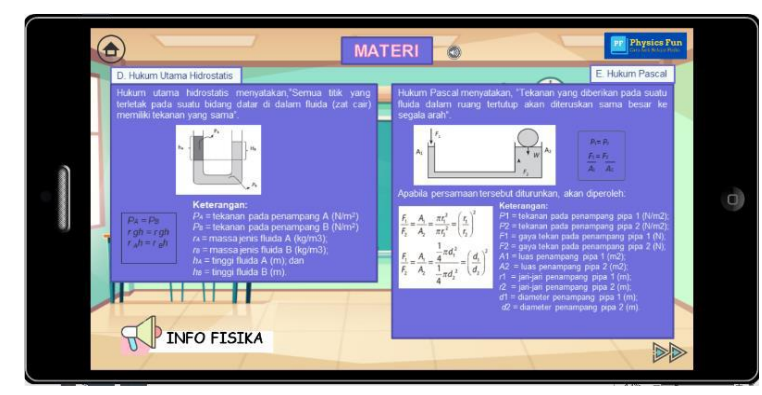

Gambar 5. Tampilan menu materi

6. Menu tokoh, berisi pengenalan mengenai tokoh-tokoh ilmuan fisika yang berkaitan dengan fluida statis.

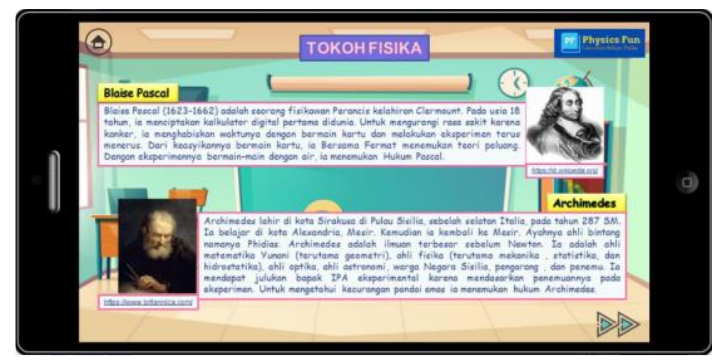

Gambar 6. Tampilan menu tokoh

7. Menu evaluasi, pada menu ini berisi soal-soal, apabila menjawab benar maka poin akan bertambah dan akan muncul symbol ceklis dan menjawab salah akan muncul symbol silang. Dalam menu evaluasi terdapat menu untuk melihat pembahasan soal.
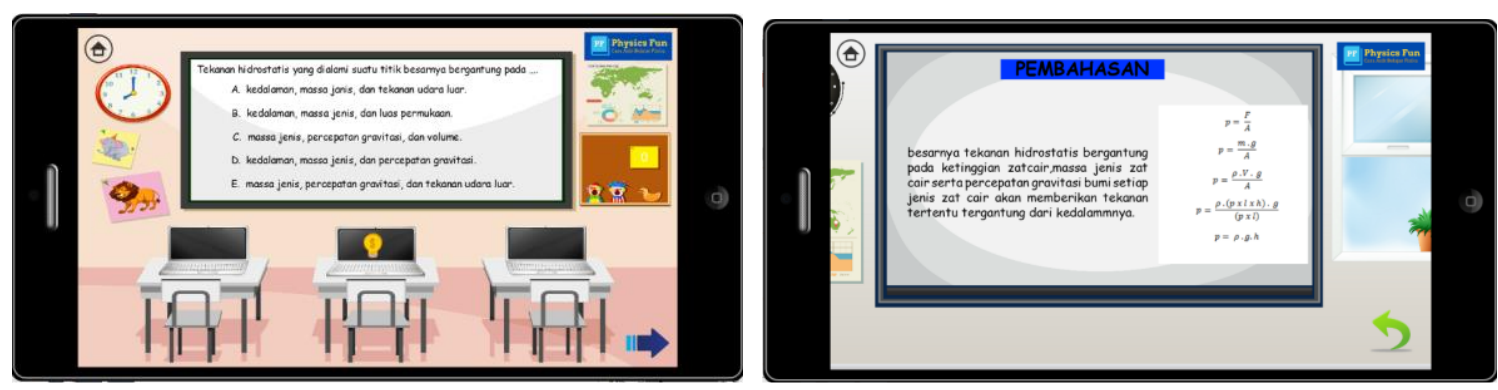
Gambar 7. Tampilan menu materi. a) tampilan soal, b) tampilan pembahasan soal

8. Menu eksperimen, berisi contoh eksperimen, video eksperimen, dan simulasi mengenai fluida statis melalu phet.

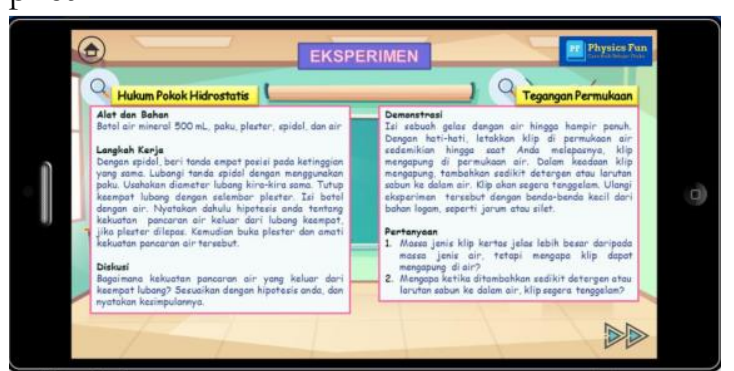

a

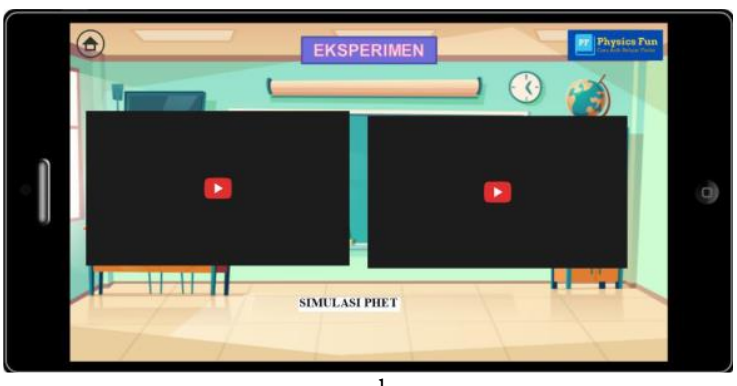

$\mathrm{b}$

Gambar 8. Tampilan menu eksperimen. a) eksperimen fluida statis, b) video eksperimen dan simulasi PHET

9. Menu penerapan, berisi penerapan atau aplikasi fluida statis dalam kehidupan sehari-hari.

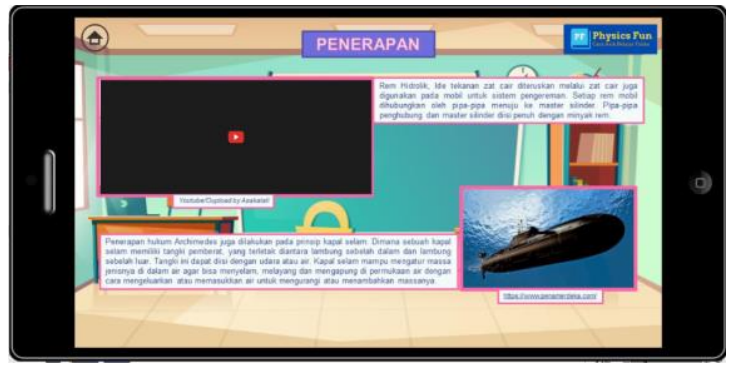

Gambar 9. Tampilan menu penerapan

10. Menu petunjuk, berisi petunjuk mengenai pengunaan dari aplikasi tersebut.

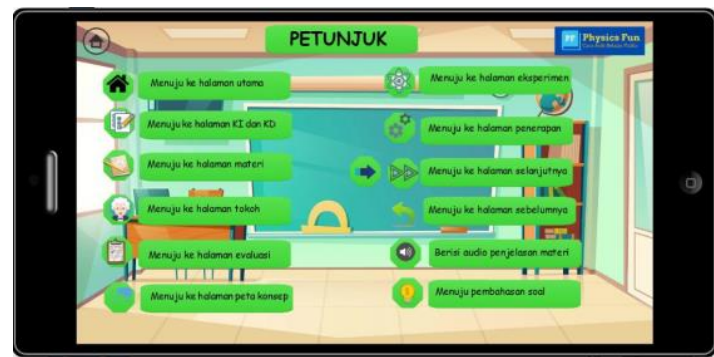

Gambar 10. Tampilan menu petunjuk

Pada tahap evaluate dilakukan uji kelayakan produk meliputi uji kelayakan media, uji kelayakan materi dan uji kelayakan Bahasa. Uji kelayakan produk ini dilakukan oleh dosen ahli dangan hasil yang ditampilkan pada tabel 1.

Tabel 1. Hasil validasi ahli

\begin{tabular}{cccc}
\hline No & Indikator Penilaian & Kecapaian Aspek & Interpretasi \\
\hline $\mathbf{1 .}$ & Aspek materi & $83,75 \%$ & Sangat valid \\
\hline $\mathbf{2 .}$ & Aspek media & $90 \%$ & Sangat valid \\
\hline $\mathbf{3 .}$ & Aspek bahasa & $85 \%$ & Sangat valid \\
\hline
\end{tabular}

\section{CONCLUSIONS}

Berdasarkan hasil penelitian yang dilakukan dapat diambil kesimpulan bahwa media pembelajaran aplikasi hebat fluida berbasis android untuk SMA kelas XI pada materi fluida statis telah berhasil dikembangkan. Berdasarkan hasil validitas yang dilakukan oleh validator ahli didapat presentase rata-rata sebesar $86,25 \%$ yang dapat disimpulkan bahwa media ini sangat valid digunakan sebagai media pebelajaran dan dapat digunakan tanpa revisi. 


\section{REFERENCES}

Agustina D, I., Asep S, R., \& Luhur S, D. (2017). Pengembangan Media Pembelajaran Fisika Mobile Learning berbasis Android. Penelitian \& Pengembangan Pendidikan Fisika, 57-62.

Azhar, \& Arsyad. (2004). Media Pembelajaran. Jakarta: Rajawali Press.

Bakri, F., Sumardani, D., \& Muliyati, D. (2019a). Integrating augmented reality into worksheets: Unveil learning to support higher-order thinking skills. AIP Conference Proceedings 2169, 020012.

Bakri, F., Sumardani, D., \& Muliyati, D. (2019b). The 3D simulation of Lorentz Force based on augmented reality technology. Journal of Physics: Conference Series 1402(6), 066038.

Bakri, F., Sumardani, D., \& Muliyati, D. (2019c). The augmented reality application for simulating electromotive force concept. Journal of Physics: Conference Series, 1402(6), 066039.

Bakri, F., Sumardani, D., \& Muliyati, D. (2021). Radioactive decay model based on augmented reality. Journal of Physics: Conference Series, $1869(1), 012192$.

Bakri, F., Wahyuni, Permana, A. H., \& Sumardani, D. (2021). Textbook enriched with video augmented reality: Contextual in motion concept learning in junior high school. AIP Conference Proceedings, 2320(1), 020054.

Hubackova, S \& Semradova, I. 2016. Evaluation of Blended Learning. Procedia-Social and Behavioral Sciences, 217(2016), 551-557.

Kemdikbud. 2019. Hasil Ujian Nasional SMA tahun 2019. Diakses melalui: https://hasilun.puspendik.kemdikbud.go.id/\#2019!sma!daya serap!99\&99\&999!a\&04\&T\&T\&1\&unbk!1! $\underline{\&}$

Kemendikbud. (2018). Laporan Hasil Ujian Nasional. Retrieved November 6, 2020, from Pusat Penilaian Pendidikan: https://hasilun.puspendik.kemdikbud.go.id

Kementerian Pendidikan dan Kebudayaan. 2016. Standar Proses Pendidikan Dasar dan Menengah. Jakarta: Kemendikbud

Kurniawan, H. (2017). Media Pembelajaran Mobile Learning Menggunakan Android (Studi Kasus : Jurusan Sistem Informasi IIB Darmajaya). Jurnal Sistem Informasi dan Telematika, 8, 46-55. Retrieved Oktober 13, 2020

Prabowo, G. (2020, Desember 21). Perkembangan Teknologi dan Komunikasi di Indonesia. Retrieved from kompas.com: https://www.kompas.com/skola/read/2020/12/21/164007469/perkembangan-teknologi-informasi-dankomunikasi-di-indonesia?page $=$ all

Purbasari, R. J. (2013). Pengembangan Aplikasi Android Sebagai Media Pembelajaran Matematika Pada Materi Dimensi Tiga Untuk Siswa SMA Kelas X. Jurnal Pendidikan Matematika. Retrieved Oktober 13, 2020, from https://jurnal-online.um.ac.id/data/artikel/artikel2C484B69ABB15E4060342947D84D09F8.pdf

Ronauli S, B., Desnita, \& Budi, E. (2018). The Development of Web-based Instructional Media for Teaching Wave Physics on Android Mobile. Jurnal Penelitian dan Pengembangan Pendidikan Fisika, 1-10.

Selwyn, \& Neil. (2011). Education and Technology Key Issues and Debates. India: Replika Press Pvt Ltd.

Sugiyono. (2017). Metode Penelitian Kuantitatif dan RひD. Bandung: Alfabeta.

Sumardani, D., Wulandari, A., Ramdina S, A. N., \& Doriza, S. (2019). Penerapan teknologi augmented reality pada media pembelajaran poster tatasurya. Prosiding Seminar Nasional Fisika (E-Journal), 8, 451-456.

Sumardani D., Midaraeni I., Sumardani N.I., (2019). Virtual reality sebagai media pembelajaran relativitas khusus berbasis google cardboard pada smartphone android. Prosiding Seminar Nasional Pendidikan KALUNI, 2, 309321.

Sumardani, D., Putri, A., Saraswati, R., Muliyati, D., \& Bakri, F. (2020). Virtual Reality Media: The Simulation of Relativity Theory on Smartphone. Formatif: Jurnal Ilmiah Pendidikan MIP A, 10(1), 13-24.

Sumardani, D., Saraswati, R., Putri, A., Bakri, F., \& Muliyati, D. (2020). System implementation of augmented reality application in student worksheet. Informatike, 8(1), 10-18.

Sumardani, D., Putri, A., Ramadhan, Z., Bakri, F., \& Muliyati, D. (2020). Augmented Physics' Lab: Magnetic Field Use Virtual Learning Media for 21st Century Students. Jurnal Pembelajaran Fisika, 8(1), 61-70.

Sumardani, D., Putri, A., \& Sumardani, N. I. (2020). E-Learning Utilizing Schoology: Teaching Theory of Relativity Using Online. Risenologi, 5(1), 48-55.

Supardi. (2012). Pengaruh Media Pembelajaran dan Minat Belajar Terhadap Hasil Belajar. Jurnal Formatif, $2(1), 71$.

Tegeh, Made, \& Dkk. (2014). Model Penelitian Pengembangan. Yogyakarta: Graha Ilmu.

Widyanirmala, W., Astra, I. M., Nasbey, H., Bakri, F., Ghina, A. I., Azizah, N., \& Nugraha, A. (2014). Pengembangan aplikasi android berupa workbook fisika sebagai pendukung mobile learning untuk siswa SMA. Prosiding Seminar Nasional Fisika (E-Journal), 3, 62-66. 